\section{Host Range of a Select Isolate of the Ericoid Mycorrhizal Fungus Hymenoscyphus ericae}

\author{
Nicole R. Gorman ${ }^{1}$ and Mark C. Starrett ${ }^{2}$ \\ Department of Plant and Soil Science, University of Vermont, Burlington, \\ VT 05405-0082 \\ Additional index words. Ericaceae, Calluna, Enkianthus, Gaultheria, Kalmia, Leucothoe, \\ Oxydendrum, Pieris, Rhododendron, Vaccinium
}

\begin{abstract}
Studies were conducted to examine the host range of a select isolate of the ericoid mycorrhizal fungus Hymenoscyphus ericae (Read) Korf and Kernan [American Type Culture Collection (ATCC) \#32985]. Host status was tested for 15 ericaceous species, including: Calluna vulgaris (L.) Hull, Enkianthus campanulatus (Miq.) Nichols, Gaultheria procumbens L., Kalmia latifolia L., Leucothoe fontanesiana Sleum., Oxydendrum arboreum (L.) DC., Pieris floribunda (Pursh) Benth. \& Hook., Rhododendron calendulaceum (Michx.) Torr., Rhododendron carolinianum Rehd., Rhododendron catawbiense Michx., Rhododendron maximum L., Rhododendron mucronulatum Turcz., Vaccinium corymbosum L., and Vaccinium macrocarpon Ait. Arbutus unedo L., an ericaceous species that forms arbutoid, not ericoid, mycorrhizae, was used as a negative control. All of the species were colonized by the ericoid isolate with the exception of Enkianthus campanulatus and the negative control. Inoculation with this isolate of $\mathrm{H}$. ericae resulted in a significant increase in shoot growth. However, intensity of root colonization was not correlated to amount of shoot growth. In fact, an increase in growth was observed in the two species that lacked fungal colonization.
\end{abstract}

Mycorrhizal symbioses are the rule rather than the exception in the plant kingdom. Ericoid mycorrhizae, the most specialized type of endomycorrhizae (Harley and Smith, 1983), are formed between a restricted number of plants in the order Ericales and a small group of ascomycetous fungi (Smith and Read, 1997). The most well known and widely researched isolate is the ascomycete Hymenoscyphus ericae (Read) Korf and Kernan (Peterson and Farquhar, 1994). Ericoid hosts have been identified in the families Ericaceae, Epacridaceae and, more recently, the nonvascular Hepaticeae (Duckett and Read, 1995; Straker, 1996).

Previous studies of ericoid mycorrhizae have produced varied growth responses in host plants (Bonfante-Fasolo et al., 1984; Bradley et al., 1981; Currah et al., 1993; Leake and Read, 1991; Powell and Bates, 1981; Read, 1995; Reich et al., 1982; Singh, 1974; Starrett, et al., 2001; Stribley et al., 1975). These inconsistent results may have resulted from the diverse sources of ericoid mycorrhizae utilized in each study. Research indicates that considerable genetic diversity may exist among ericoid

Received for publication 17 July 2002. Accepted for publication 2 Jan. 2003. This research was funded by a Federal Hatch Grant. Use of trade names in this publication does not imply endorsement by the Vermont Agricultural Experiment Station or the U.S. Dept. of Agriculture-Agricultural Research Service of products named nor criticism of similar ones not mentioned. Statistical assistance of Gary Badger and John Aleong is gratefully acknowledged. From a thesis submitted by N.R.G. in partial fulfillment of the requirements of an MS degree.

${ }^{1}$ Former Graduate Assistant.

${ }^{2}$ Associate Professor; to whom reprint requests should be addressed. E-mail: Mark.Starrett@uvm.edu fungi (Perotto et al., 1995). Select ericaceous species have been inoculated with unidentified ericoid fungi, often using peat originating from native habitats of ericaceous species, as an inoculum (Allaway and Ashford, 1996; Bradley et al., 1981; Leake and Read, 1989, 1991; Mitchell and Read, 1981; Pearson and Read, 1973b; Powell and Bates, 1981; Reich et al., 1982). The first ericoid fungus to be taxonomically identified, H. ericae (Read, 1974), is the most intensely researched species (Peterson and Farquahar, 1994). However, other studies have used diverse sources of fungal isolates collected from all over the world (Currah et al., 1993; Leake and Read, 1991; Pearson and Read, 1975; Straker and Mitchell, 1985). Many of these studies failed to identify a specific fungal strain (Bannister and Norton, 1974;
Berta and Bonfante-Fasolo, 1983; Bradley et al., 1981; Leake and Read, 1989). Other studies have attempted to evaluate the host range of ericoid fungi, but have inoculated with unidentified ericoid fungal isolates, described, for example as, "dark, slow-growing cultures" (Pearson and Read, 1973b; Reed, 1987).

To date there have been no studies that investigate the host range of a select isolate of the ericoid endophyte $H$. ericae. Therefore, the objective of this study was to evaluate the host range using select species within the Ericaceae by inoculating with a specific isolate of H. ericae.

\section{Materials and Methods}

Seed of 15 ericaceous species was obtained from commercial seed suppliers [Sheffield's Seed Co. (Lock, N.Y.) and F.W. Schumacher Co. (Sandwich, Mass.)]. Seed was cleaned and counted under a dissecting microscope to select seeds of similar size, color, and fullness. Preliminary trials were conducted to determine the approximate number of days to germination for each species. Species were grouped (A-C) according to number of days to germination (Table 1). Grouping species enabled all species to be inoculated and transplanted at the same growth stage. Simultaneous transplant allowed for a single harvest date for each replication.

Seed treatment and aseptic germination. On 30 Oct. 1998, seed from group A (Table 1) was surface-disinfested with a dilute sodium hypochlorite solution $(0.5 \%$ to $1.0 \%)$ also containing the surfactant polyoxyethylene sorbitan monolaurate [Tween $20(0.005 \%)$ ]. Bleach concentrations were determined during preliminary trials to reduce contamination yet retain viability of the seed. As a result, dilution of the solution used in surface-disinfestation varied between species (Table 1). Seed and bleach solution were stirred vigorously for 15 min, the solution decanted, and seed rinsed with sterile, distilled water. Seeds were transferred to $60 \times 15$-mm polystyrene disposable petridishes containing $10 \mathrm{~mL}$ sterile water agar $\left(6 \mathrm{~g} \cdot \mathrm{L}^{-1}\right)$. There were five seeds per dish and a total of six dishes per species. The dishes were sealed with Parafilm "M" and enclosed in 0.95-L re-

Table 1. Seed treatment protocol for aseptic germination of select ericaceous species.

\begin{tabular}{|c|c|c|c|}
\hline Ericaceous species & Abbreviation of species & Group $^{2}$ & Sodium hypochlorite treatment \\
\hline Calluna vulgaris & CALL & $\bar{A}$ & $0.5 \%$ \\
\hline Pieris floribunda & PIER & A & $1.0 \%$ \\
\hline Vaccinium corymbosum & VACC & A & $0.5 \%$ \\
\hline Arbutus unedo & ARBU & B & $0.5 \%$ \\
\hline Gaultheria procumbens ${ }^{\mathrm{x}}$ & GAUL & B & $0.5 \%$ \\
\hline Rhododendron calendulaceum & RCAL & B & $0.8 \%$ \\
\hline Rhododendron carolinianum & RCAR & B & $0.5 \%$ \\
\hline Rhododendron catawbiense & RCAT & B & $0.5 \%$ \\
\hline Rhododendron maximum & RMAX & B & $0.8 \%$ \\
\hline Rhododendron mucronulatum & RMUC & B & $0.5 \%$ \\
\hline Vaccinium macrocarpon ${ }^{\mathrm{y}}$ & VACM & B & $1.0 \%$ \\
\hline Enkianthus campanulatus & ENKI & $\mathrm{C}$ & $1.0 \%$ \\
\hline Kalmia latifolia & KALM & $\mathrm{C}$ & $0.5 \%$ \\
\hline Leucothoe fontanesiana & LEUC & $\mathrm{C}$ & $0.5 \%$ \\
\hline Oxydendrum arboreum & OXYD & $\mathrm{C}$ & $1.0 \%$ \\
\hline
\end{tabular}

${ }^{z}$ Species are grouped according to number of days to germination. Grouping allowed all species to be transplanted and inoculated at the same growth stage. A at $28 \mathrm{~d} ; \mathrm{B}$ at $21 \mathrm{~d} ; \mathrm{C}$ at $14 \mathrm{~d}$.

${ }^{y}$ Seeds were cold stratified for $30 \mathrm{~d}$ at 1 to $5^{\circ} \mathrm{C}$ after surface disinfestation procedure.

${ }^{\mathrm{x}}$ Seeds were cold stratified for $60 \mathrm{~d}$ at 1 to $5{ }^{\circ} \mathrm{C}$ after surface disinfestation procedure. 
sealable plastic bags. The bags were placed in a controlled-environment chamber maintained at $22{ }^{\circ} \mathrm{C}$ day $/ 20{ }^{\circ} \mathrm{C}$ night temperature. A 16$\mathrm{h}$ photoperiod was provided by cool-white fluorescent lamps and incandescent bulbs. Lamps and bulbs provided an average photosynthetic photon flux [PPF $(400-700 \mathrm{~nm})]$ of $251 \mu \mathrm{mol} \cdot \mathrm{m}^{-2} \cdot \mathrm{s}^{-1}$ as measured at the top of the dishes. These and all other light measurements were taken with a LI-COR Quantum Sensor and recorded with a LI-COR 1000 Data Logger (LI-COR, Lincoln, Nebr.). Petri dishes were scanned weekly for contamination. Contaminated dishes were removed from the bags and discarded.

Three species, Arbutus unedo, Gaultheria procumbens, and Vaccinium macrocarpon, required cold stratification following surface-disinfestation procedure. Seeds of these species were surface-disinfested prior to the other species examined to allow for their required stratification period. During stratification, seeds were placed in the dark in a refrigerator maintained at 1 to $4^{\circ} \mathrm{C}$ for $30-60$ d (Table 1).

Preparation of inoculum. An actively growing fungal isolate of $\mathrm{H}$. ericae was obtained from the American Type Culture Collection [ATCC\# 32985 (Rockville, Md.)]. Using aseptic techniques, the isolate was subcultured and grown on Bacto malt agar $\left(45 \mathrm{~g} \cdot \mathrm{L}^{-1}\right)$ for $\approx 8$ weeks. Fungal cultures were placed in a controlled-environment chamber maintained at constant temperature of $23{ }^{\circ} \mathrm{C}$. During incubation, a 16-h photoperiod was provided by cool-white fluorescent tubes suspended $24 \mathrm{~cm}$ above the tops of the petri dishes. Tubes emitted an average $P P F$ of $17 \mu \mathrm{mol} \cdot \mathrm{m}^{-2} \cdot \mathrm{s}^{-1}$ as measured at the top of the petri dishes. Care was taken to select dark, slow-growing, uniform cultures as an inoculum.

Preparation of growing media. On 20 Nov. 1998, 3 weeks prior to transplant of seedlings from the first replication, sixty $75-\mathrm{mL}$ vials were filled with $25 \mathrm{~mL}$ vermiculite moistened with $5 \mathrm{~mL}$ distilled water and $6 \mathrm{~mL}$ Woody Plant Medium [WPM (Lloyd and McCown, 1980)] supplemented with sucrose $\left(5 \mathrm{~g} \cdot \mathrm{L}^{-1}\right)$. This medium was adjusted to a $\mathrm{pH}$ of 5.2 with $1 \mathrm{~N} \mathrm{HCl}$ prior to addition to vials. Vermiculite was chosen for use as the growing medium as opposed to using native soil excised from an existing ericaceous plant community due to the problems associated with sterilizing soils containing peat (Stribley et al., 1975). Vials were covered with Magenta-caps (Magenta Corp., Chicago) and autoclaved for $15 \mathrm{~min}$ at $121^{\circ} \mathrm{C}$. Vials were allowed to cool overnight in a laminar flow hood. On 21 Nov. 1998, hyphae of ericoid mycorrhizal fungi were transferred aseptically to vials containing the vermiculite media. Wefts of $\approx 3 \mathrm{~mm}^{3}$ growing actively on the surface of 1-month-old malt agar cultures of $H$. ericae were transferred to 30 vials. A second set of 30 vials remained noninoculated (controls). Vials were recapped, sealed with Parafilm "M," and placed in Magenta 7-way tray racks (Magenta Corp.). The racks allowed for $0.5-\mathrm{cm}$ spacing between vials. To create similar light and temperature conditions for all cultures, vials containing only the growing media were used as a guard-row and placed around the perimeter of the rack. The racks were placed in a controlled-environment chamber maintained at $25^{\circ} \mathrm{C}$ day $/ 22^{\circ} \mathrm{C}$ night temperature. A 16-h photoperiod was provided by cool-white florescent tubes suspended $2 \mathrm{~cm}$ above the tops of the vials. Lamps provided an average $P P F$ of $58 \mu \mathrm{mol} \cdot \mathrm{m}^{-2} \cdot \mathrm{s}^{-1}$ as measured at the top of the vials. These light and temperature conditions were used for the remainder of the study. This procedure was repeated for each subsequent replication.

Transplant. After incubation, seedlings with fully extended cotyledons were chosen for transplanting. Seedlings were aseptically transferred to the vials. An additional $1.0 \mathrm{~mL}$ of sterile, liquid WPM was added to each vial at the time of transplant. Vials were recapped with Magenta-caps and sealed with Parafilm "M." The racks were placed back into the controlled-environment chamber following transplant. Transplant of seedlings of each replicate was separated by 1 week.

Harvest. On 10 Feb. 1999, 60 d from transplant of seedlings, the first replication was harvested. Plants were divided into shoots and roots. Root samples were prepared to determine extent of fungal colonization. Each root sample was placed in a beaker and gently washed in distilled water. Any remaining growing media was teased from the roots in distilled water under a dissecting microscope. The samples were then cleared and stained following a protocol adapted from Brundrett et al. (1984) and examined using bright field microscopy. To quantify root colonization, individual roots from each seedling were randomly selected and examined for the presence of infected cells. Five random views per root system were sampled at $\times 400$. Thirty contiguous cortical cells were counted per view to determine the percentage of cells colonized. Each view under the scope was considered an observation. An average of five observations was calculated as the mean colonization of a single seedling.

Experimental design and statistical anal$y$ sis. The experimental design consisted of four replicates, or blocks, consisting of 15 species that were staggered by $\approx 1$ week for manageability in set-up and evaluation. Each replicate contained 60 vials, representing four seedlings (one per vial) of each of the 15 species, two of which were inoculated with $H$. ericae, and two that remained noninoculated. The 60 seedlings were randomized spatially within each replicate. This design constitutes a randomized complete block (RCBD), in which 30 treatments have a factorial structure (15 species $\times 2$ inoculation states). For each seedling, an estimate of intensity of colonization was based on the average of five randomly determined $\times 400$ views of randomly selected hair roots, each resulting in an estimate of percent of root cells colonized. Number of leaves and stem length was also recorded for each seedling.

Statistical analyses were performed using SAS (SAS Institute, 1989a, 1989b). Species comparisons on colonization intensity (i.e., mean percent root cell colonization) are based on analysis of variance limited to the inoculated seedlings. In order to satisfy the homogeneity of variance assumption associated with the analysis of variance, data corresponding to percent colonization was arcsine transformed and leaf number was square root transformed prior to analysis. Although statistical significance was based on transformed data, means presented in tables and figures represent nontransformed data. All $\mathrm{F}$ tests corresponding to treatment comparisons utilized the Replicate $\times$ Treatment mean square as the error term. Pairwise comparisons are based on Fisher's LSD procedure. Statistical significance was determined using $P<0.05$.

\section{Results}

All of the ericaceous species tested, including $G$. procumbens, $K$. latifolia, L. fontanesiana, O. arboreum, P. floribunda, R. calendulaceum, $R$. carolinianum, $R$. catawbiense, $R$. maximum, $R$. mucronulatum, V. corymbosum, and $V$. macrocarpon, with the exception of $E$. campanulatus and the negative control, A. un$e d o$, were colonized by the isolate (Table 2). The lack of colonization in A. unedo was expected since this species forms arbutoid, not ericoid, mycorrhizae. Surprisingly, E. campanulatus, a species thought to form typical ericoid mycorrhizae, also was not colonized. Because the host status of the latter species has not been tested with any ericoid mycorrhizal fungus, this lack of colonization is of note.

Significant differences were detected in mean percent colonization among species $\left(\mathrm{F}_{14,39}=13.42, P<0.0001\right)$. The greatest degree of infection was observed in $R$. carolinianum (65\%), and the least was found in E. campanulatus $(0 \%)$. Significantly greater percent colonization was observed in the species $R$. carolinianum, P. floribunda, V. macrocarpon, $K$. latifolia, and L. fontanesiana as compared to the species $R$. calendulaceum, O. arboreum,

Table 2. Mean percent root cell colonization of select ericaceous species by Hymenoscyphus ericae (ATCC \#32985) after incubation for $60 \mathrm{~d}$ in vitro.

\begin{tabular}{lcr}
\hline Species & Mean $^{\mathrm{z}}$ & SD $^{\mathrm{y}}$ \\
\hline Rhododendron carolinianum $^{\mathrm{x}}$ & $64.6 \mathrm{a}$ & 20.0 \\
Pieris floribunda & $64.3 \mathrm{a}$ & 22.5 \\
Vaccinium macrocarpon $_{\text {Kalmia latifolia }}^{\mathrm{x}}$ & $60.9 \mathrm{ab}$ & 8.0 \\
Leucothoe fontanesiana & $58.9 \mathrm{ab}$ & 11.2 \\
Rhododendron maximum & $58.1 \mathrm{ab}$ & 12.5 \\
Rhododendron catawbiense & $41.9 \mathrm{a}-\mathrm{c}-\mathrm{d}$ & 27.2 \\
Vaccinium corymbosum $_{\text {Gaultheria procumbens }}$ & $40.6 \mathrm{~b}-\mathrm{d}$ & 15.9 \\
Rhododendron calendulaceum & $39.8 \mathrm{~b}-\mathrm{d}$ & 6.9 \\
Oxydendrum arboreum & $29.8 \mathrm{~cd}$ & 19.6 \\
Calluna vulgaris & 3.2 \\
Rhododendron mucronulatum & $23.4 \mathrm{de}$ & 5.5 \\
Arbutus unedo & $0 \mathrm{f}$ & 12.5 \\
Enkianthus campanulatus & $0 \mathrm{f}$ & 0 \\
\hline
\end{tabular}

${ }^{\mathrm{z}}$ Means are based on four replicates of two seedlings each. Percent colonization based on five random views per seedling. Means not sharing a common letter are significantly different (Fisher's LSD, $P<$ $0.05)$.

${ }^{y}$ Standard deviation associated with replicates.

xMean based on three replicates due to either inadequate germination or death at transplant. Means are calculated from values of living plants only. 

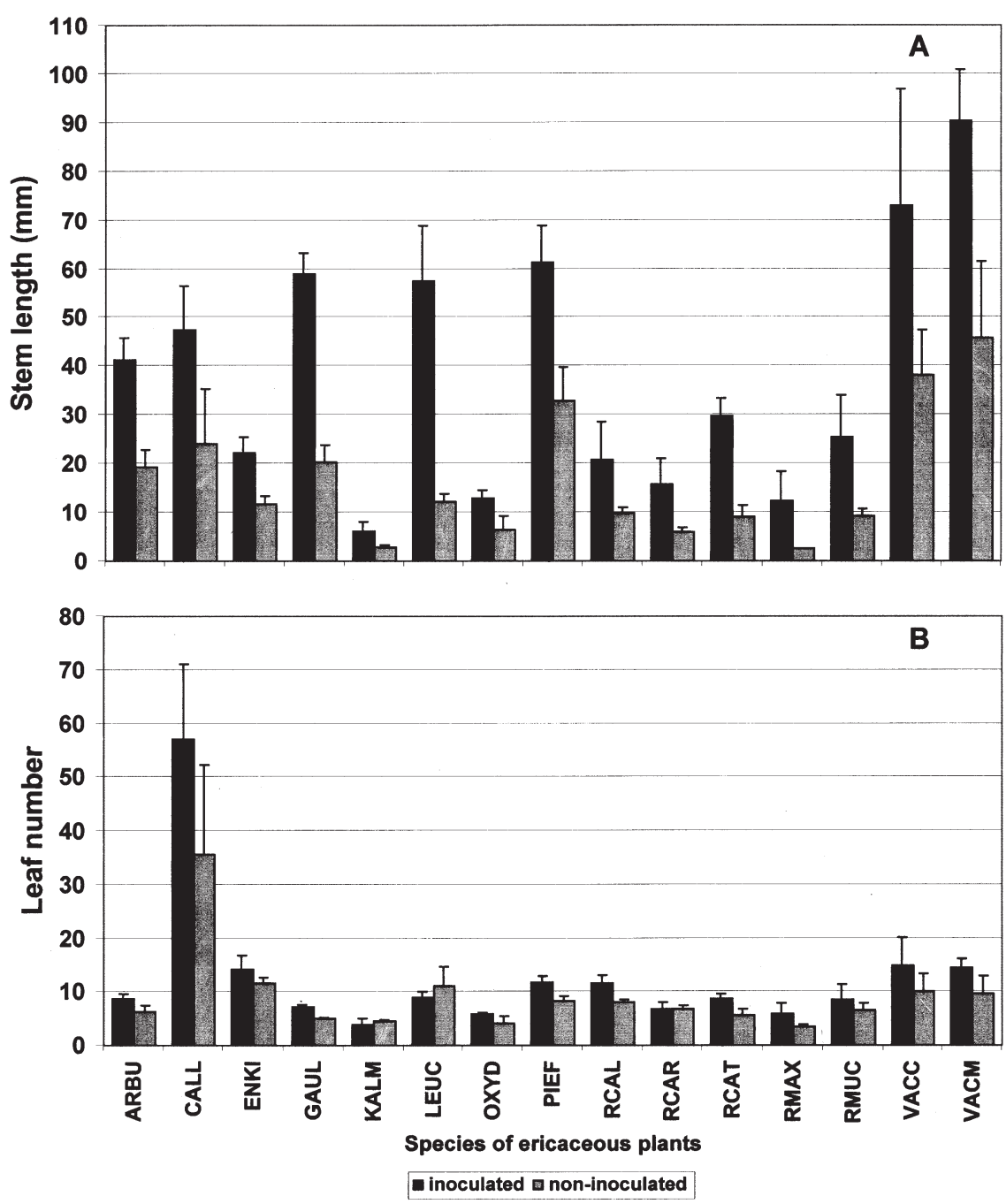

Fig. 1. In vitro grown seedlings of ericaceous species inoculated with Hymenoscyphus ericae (ATCC \#32985). (A) mean stem length (+SE). (B) mean leaf number (+SE). Significant differences between inoculated and noninoculated, independent of species $(P<0.05)$.

C. vulgaris, and R. mucronulatum. Rhododendron mucronulatum exhibited the least degree of infection of all the colonized species and differed significantly from all species except C. vulgaris.

Analyses relating to stem length indicated a positive response to inoculation (Fig. 1A). Statistical analysis revealed significant differences in mean stem length between inoculated and noninoculated seedlings $\left(\mathrm{F}_{1,80}=52.95, P=\right.$ $0.0001)$ although there was no evidence that this difference was species specific $\left(\mathrm{F}_{14,80}=1.48, P\right.$ $=0.140$ ). In general, inoculated seedlings exhibited a relatively large increase in mean stem length across all inoculated species. In fact, stem length across all species was increased more than 2-fold over the noninoculated seedlings. The greatest increase was observed in L. fontanesiana, being more than 5-fold that of the noninoculated seedlings.

Analyses relating to leaf number also indicated a positive response to inoculation (Fig. 1B). Statistical analysis revealed significant differences in mean leaf number between inoculated and noninoculated seedlings $\left(F_{1,80}\right.$ $=9.08, P=0.004)$ although there was no evidence that this difference was specific to species $\left(\mathrm{F}_{14,80}=0.68, P=0.784\right)$. The mean leaf number across all inoculated species increased $\approx 1.3 \times$ that of the noninoculated seedlings. All of the inoculated species exhibited an increase in leaf number as compared to the noninoculated seedlings, with the exception of $K$. latifolia, L. fontanesiana, and $R$. carolinianum. For the species $R$. carolinianum, no change was observed in leaf number of inoculated as compared to noninoculated seedlings. Kalmia latifolia and L. fontanesiana exhibited a decrease in leaf number as compared to noninoculated seedlings. Interestingly, A. unedo, one of the species that was not colonized by H. ericae, exhibited a greater percent increase in leaf number than several colonized species including: $K$. latifolia, L. fontanesiana, O. arboreum, $R$. carolinianum, $R$. maximum, and $R$. mucronulatum.

Statistical analysis revealed that there was no correlation of intensity of colonization to an increase in shoot length or leaf number. Rhododendron carolinianum was the most heavily infected; however, inoculated seedlings did not respond with an increase in stem length or leaf number as compared to the other inoculated species. All of the inoculated species, with the exception of $K$. latifolia and L. fontanesi$a n a$, were observed to have a greater percent increase in leaf number than the more heavily colonized $R$. carolinianum. Additionally, inoculated seedlings of $G$. procumbens, $L$. fontanesiana, $R$. catawbiense, $R$. maximum, and $R$. mucronulatum all exhibited a greater percent increase in stem length as compared to $R$. carolinianum. In fact, E. campanulatus, which was not colonized at all, exhibited an increase in both shoot length and leaf number and A. unedo, also not colonized by H. ericae, exhibited a significant increase in stem length. The possible factors contributing to increased growth with inoculation of $H$. ericae with low or without any root colonization are considered in the following discussion.

\section{Discussion}

The isolation, culture, and development of typical mycorrhizal structures are only the first steps in determination of the nature of the mycorrhizal relationship (Leake and Read, 1991). One of the complexities of mycorrhizae is demonstrated in this study by the inability to differentiate between the effect of inoculation and the effect of mycorrhiza formation. For practical purposes, an additional difficulty lies in the determination of which host responses are most appropriate to measure for accurate prediction of increased host productivity.

Percent colonization may not be a good indicator of plant productivity, indicated by the lack of correlation in this study between colonization intensity and the two growth responses (leaf number and stem length). Other researchers have also observed a lack of correlation between intensity of colonization and growth response in ericaceous plants inoculated with ericoid fungi (Starrett et al., 1996). In fact, there may be differences in the host-fungus relationship between species as a result of the varied conditions under which the associations have evolved. Read (1996) hypothesized that the function of ericoid mycorrhiza may actually differ among ericaceous populations. Additionally, Goulart et al. (1993) surveyed native and commercial populations of Vaccinium in the northeastern and midwestern United States and found a high degree of variation in infection. Again, this indicates that there could be other factors contributing to the variation in intensity of colonization.

The increase in growth in the species $E$. campanulatus and $A$. unedo, both without colonization, may seem unusual. However, similar results have been shown in other studies. Linderman and Call (1977) also observed an increase in root formation without mycorrhizal formation in ericaceous species. Select ectomycorrhizae have been shown to release growth factors, such as auxin, cytokinins, gibberellins, and B-vitamins in vitro (Slankis, 1973), but release of such compounds has not been demonstrated by $H$. ericae. It is certainly possible that the physical and/or chemical composition of the growing media was changed by the inoculum. However, none of these factors have been investigated in the present study. 
Variability in colonization of seedlings within species may have resulted from the genetic variability associated with seed propagation and the short duration of the project. Seedlings may not have had adequate time for uniform mycorrhizal development. A possible method for reduction of variability due to genetic variation is the use of clonal plant material, such as rooted microcuttings, and needs further investigation.

The isolate of $H$. ericae used as the inoculum for this study was originally isolated from $C$. vulgaris. Therefore, one would expect this species to be intensely colonized. To the contrary, $C$. vulgaris exhibited relatively low root colonization (Table 2). Starrett et al. (1996) also observed this lack of host specificity among ericoid isolates. Despite this low colonization, $C$. vulgaris had the greatest percent increase in leaf number of all the species tested. An $\approx 2$-fold increase in stem length was also observed; however, the percent increase was less than all inoculated species with the exception of V.corymbosum, P. floribunda, and E. campanulatus.

Read (1983) stated that all plants in the Ericaceae are mycorrhizal. Therefore, the lack of colonization observed in E. campanulatus is of particular interest. Further study is necessary to determine whether E. campanulatus forms another type of association, such as arbutoid mycorrhizae that develop on other species in the Ericales, such as A. unedo and Arctostaphylos uva-ursi (L.) Spreng.

\section{Literature Cited}

Allaway, W.G. and A.E. Ashford. 1996. Structure of hair roots in Lysnema ciliatum R. Br. and its implications for their water relations. Ann. Bot. 77:383-388.

Bannister, P. and W.M. Norton. 1974. The response of mycorrhizal and non-mycorrhizal rooted cuttings of heather [Calluna vulgaris (L.) Hull] to variations in nutrient and water regimes. New Phytol. 73:81-89.

Berta, G. and P. Bonfante-Fasolo. 1983. Apical meristems in mycorrhizal and uninfected roots of Calluna vulgaris (L.) Hull. Plant Soil 71: 285-291.

Bonfante-Fasolo, P., V. Gianinazzi-Pearson, and L. Martinengo. 1984. Ultrastructural aspects of endomycorrhizas in the Ericaceae. IV. Comparison of infection by Pezizella ericae in host and nonhost plants. New Phytol. 98:329-333.

Bradley, R., A.J. Burt, and D.J. Read. 1981. My- corrhizal infection and resistance to heavy metal toxicity in Calluna vulgaris. Nature 292: 335-337.

Brundrett, M.C., Y. Piché, and R.L. Peterson. 1984. A new method for observing the morphology of vesicular-arbuscular mycorrhizae. Can J. Bot. 62:2128-2134.

Currah, R.S., A. Tsuneda, and S. Murakami. 1993. Morphology and ecology of Phialocephala fortinii in roots of Rhododendron brachycarpum. Can. J. Bot. 71:1639-1644.

Duckett, J.G. and D.J. Read. 1995. Ericoid mycorrhizas and rhizoid-ascomycete associations in liverworts share the same mycobiont: Isolation of the partners and resynthesis of the associations in vitro. New Phytol. 129:439-447.

Goulart, B.L., M.L. Schroeder, R.L. Darnell, J.R. Clark, and W.F. Wilcox. 1993. Blueberry mycorrhizae: Current knowledge and future directions. In: Proc. 5th Intl. Symp. Vaccinium Cult. Acta Hort. 346:230-239.

Harley, J.L. and S.E. Smith. 1983. Mycorrhizal symbiosis. Academic Press, New York.

Leake, J.R. and D.J. Read. 1989. The effects of phenolic compounds on nitrogen mobilisation by ericoid mycorrhizal systems. Agr. Ecol. Environ. 29:225-236.

Leake, J.R. and D.J. Read. 1991. Experiments with ericoid mycorrhiza, p. 435-460. In: J.R. Norris, D.J. Read, and A.R. Varma (eds.). Methods in microbiology, vol. 23. Academic Press, San Diego, Calif.

Linderman, R.G. and C.A. Call. 1977. Enhanced rooting of woody plant cuttings by mycorrhizal fungi. J. Amer. Hort. Sci. 105(5):629-632.

Lloyd, O. and B. McCown. 1980. Commerciallyfeasible micropropagation of mountain laurel, Kalmia latifolia, by use of shoot-tip culture. Proc. Intl. Plant Prop. Soc. 30:421-437.

Mitchell, D.T. and D.J. Read. 1981. Utilization of inorganic and organic phosphates by the mycorrhizal endophytes Vaccinium macrocarpon and Rhododendron ponticum. Trans. Br. Mycol. Soc. 76:255-260.

Pearson, V. and D.J. Read. 1973b. The biology of mycorrhiza in the Ericaceae. I. The isolation of the endophyte and synthesis of mycorrhizas in aseptic culture. New Phytol. 72:371-379.

Pearson, V. and D.J. Read. 1975. The physiology of the mycorrhizal endophyte of Calluna vulgaris, part I. Trans. Br. Mycol. Soc. 64:1-7.

Peterson, R.L. and M.L. Farquhar. 1994. Mycorrhizas - Integrated development between roots and fungi. Mycologia 86:311-326.

Perotto, S., R. Peretto, A. Faccio, A. Schubert, A. Varma, and P. Bonfante. 1995. Ericoid mycorrhizal fungi: Cellular and molecular bases of their interaction with the host plant. Can. J. Bot. 73:S557-S568.

Powell, C.L. and P.M. Bates. 1981. Ericoid my- corrhizae stimulate fruit yield of blueberry. HortScience 16:655-656.

Read,D.J. 1974. Pezizella ericae sp. nov., the perfect state of a typical mycorrhizal endophyte of ericaceae. Trans. Br. Mycol. Soc. 63:381-382.

Read, D.J. 1983. The biology of mycorrhiza in the Ericales. Can. J. Bot. 61:985-1004.

Read, D.J. 1995. The biology of mycorrhiza in the Ericaceae. XVIII. Chitin degradation by Hymenoscyphus ericae and transfer of chitin-nitrogen to the host plant. New Phytol. 131:369-375.

Read, D.J. 1996. The structure and function of the ericoid mycorrhizal root. Ann. Bot. 77: 365-374.

Reed, M.L. 1987. Ericoid mycorrhiza of Epacridaceae in Australia, p. 335. In: D.M. Sylvia, L.L. Hung, and J.H. Graham (eds.). Proc. 7th North Amer. Conf. on Mycorrhizae, 3-8 May 1987. Univ. of Florida, Gainesville.

Reich, L.A., R.F. Korcak, and A.H. Thompson. 1982. The effect of selected soil factors on growth and nutrient content of highbush blueberry (Vaccinium corymbosum L.) J. Amer. Soc. Hort. Sci. 107:943-946.

SAS Institute. 1989a. SAS/STAT user's guide, ver. 6 , 4th ed., vol. 1. SAS Inst., Cary, N.C.

SAS Institute. 1989b. SAS/STAT user's guide, ver. 6, 4th ed., vol. 2. SAS Inst., Cary, N.C.

Singh, K.G. 1974. Mycorrhiza in the Ericaceae with special reference to Calluna vulgaris. Sven. Bot. Tidskr. 68:1-16.

Slankis, V. 1973. Hormonal relationships in Mycorrhizae, p. 231-298. In: G.C. Marks and T.T. Kozlowski (eds.). Ectomycorrhizae, their ecology and physiology. Academic Press, New York.

Smith, S.E. and D.J. Read. 1997. Mycorrhizal symbiosis. 2nd ed. Academic Press, San Diego, Calif.

Starrett, M.C., F.A. Blazich, L.F. Grand and S.R. Shafer. 1996. Response of microshoots of mountain andromeda to in vitro ericoid mycorrhizal inoculation, p. 239-242. Proc. Southern Nurserymen's Assn. Res. Conf., 41st Annu. Rpt.

Starrett, M.C., F.A. Blazich, L.F. Grand, and S.R. Shafer. 2001. In vitro colonization of micropropagated Pieris floribunda by ericoid mycorrhizae. II. Effects on acclimatization and growth. HortScience 36:357-359.

Straker, C.J. 1996. Ericoid mycorrhiza: Ecological and host specificity. Mycorrhiza 6:215-225.

Straker, C.J. and D.T. Mitchell. 1985. The characterization and estimation of polyphosphates in endomycorrhizas of the Ericaceae. New Phytol. 99:431-440.

Stribley, D.P., D.J. Read, and R. Hunt. 1975. The biology of mycorrhiza in the Ericaceae V: The effects of mycorrhizal infection, soil type and partial soil sterilization (by gamma-irradiation) on growth of cranberry (Vaccinium macrocarpon Ait.). New Phytol. 75:119-130. 